\title{
EMPIRE OF VINES
}


NATURE AND CULTURE IN AMERICA

Marguerite S. Shaffer, Series Editor

Volumes in the series explore the intersections between the construction of cultural meaning and perception and the history of human interaction with the natural world. The series is meant to highlight the complex relationship between nature and culture and provide a distinct position for interdisciplinary scholarship that brings together environmental and cultural history. 


\title{
EMPIRE OF VINES
}

:

\author{
WINE CULTURE \\ IN AMERICA
}

\section{ERICA HANNICKEL}

\author{
$\overline{\text { PENN }}$ \\ UNIVERSITY OF PENNSYLVANIA PRESS \\ PHILA DEL PHIA
}


Copyright (c) 2013 University of Pennsylvania Press

All rights reserved. Except for brief quotations used for purposes of review or scholarly citation, none of this book may be reproduced in any form by any means without written permission from the publisher.

$$
\begin{gathered}
\text { Published by } \\
\text { University of Pennsylvania Press } \\
\text { Philadelphia, Pennsylvania 19104-4112 } \\
\text { www.upenn.edu/pennpress }
\end{gathered}
$$

Printed in the United States of America on acid-free paper

$$
\begin{array}{llllllllll}
10 & 9 & 8 & 7 & 6 & 5 & 4 & 3 & 2 & 1
\end{array}
$$

Library of Congress Cataloging-in-Publication Data

Hannickel, Erica.

Empire of vines : wine culture in America / Erica Hannickel. -1 st ed.

p. cm. - (Nature and culture in America)

Includes bibliographical references and index.

ISBN 978-0-8122-4559-2 (hardcover : alk. paper)

1. Viticulture-United States-History-19th century.

2. Wine and wine making-United States-History-19th century. 3. Grapes-United States-History-19th century. I.

Title. II. Series: Nature and culture in America.

TP557.H358 2013

$663.20973-\mathrm{dc} 23$ 
For my grandmothers 

The first record of America is also a record of its grapes.

Liberty Hyde Bailey

Sketch of the Evolution of Our Native Fruits, 1898

How beautifully prophetic is the emblematic vine of the destiny of man.

Jno. S. Reid

The Horticulturist, 1862

The vine and the American people are not unlike [one another]. They require room to spread themselves, and do not thrive under restraint.

G. W. Campbell

The Horticulturist, 1874

The gold of the Sierra did not build cities as surely as will the vines of its foothills.

Charles A. Wetmore

Californian, 1880 
